Aleksandra Rybińska

(Uniwersytet Łódzki

Wydział Filozoficzno-Historyczny)

\title{
ZAGADNIENIE METODOLOGII BADAŃ W NAUKACH HISTORYCZNYCH I MEDYCZNYCH - PROBLEM INTERDYSCYPLINARNOŚCI
}

W

dzisiejszych czasach badania interdyscyplinarne stają się coraz bardziej popularne. $Z$ tym problemem musi zmierzyć się wielu badaczy. Specyfika procedur badawczych w obrębie poszczególnych dziedzin różni się od siebie. Istnieją zakresy badawcze, które ciężko zakwalifikować do jednej metody poznawczej. Jako doktorantka historii na Uniwersytecie Łódzkim, pisząca pracę z historii medycyny w wojskowej służbie zdrowia w latach 1918-1939, napotkałam właśnie na taki problem. Status medycyny w mojej metodzie badawczej ma charakter humanistyczny. Postanowiłam swoje przemyślenia oraz doświadczenia z zakresu poznawania i badania obu dziedzin zebrać i przedstawić w postaci niniejszego artykułu.

Pod pojęciem metodologii badań rozumiem naukę zajmującą się sposobem pomiaru zachodzących zjawisk, które badacz chce zmierzyć. Jest to pewien zbiór reguł dotyczących tego jak badać, kogo badać, czym badać, gdzie badać. Celem metodologii badań jest opracowanie coraz to lepszych sposobów pomiaru (badania) zjawisk, udoskonalanie bieżących. Im lepsza jest metoda badania tym wierniejsze wyniki uzyskamy. Kluczem do rzetelnego pomiaru interesującego nas zjawiska jest dobór odpowiedniej metody badawczej (techniki pomiaru). Każda gałąź nauki opracowała i opracowuje własne metody badawcze, po to, aby jak najlepiej mierzyć interesujące ich zjawiska.

Celem mojego tekstu jest przedstawienie, różnic oraz podobieństw w metodologii badań nauk medycznych oraz nauk historycznych. Ukazanie ,ludzkiej twarzy medycyny". Chcę pokazać w jaki sposób: my historycy postrzegamy problemy medycyny (historii medycyny) i jak radzimy sobie z nauką, która jest uznawana za ścisłą. Dwa wydawałoby się różne środowiska, a mające wiele wspólnego.

Podział nauk jest bardzo rozbudowany i z biegiem czasu w różnych epokach podejście do nich zmieniało się. Już Arystoteles podzielił je na: teoretyczne (poznanie), praktyczne (reguły postępowania) oraz wytwórcze (reguły tworzenia). Dzisiaj zasadniczo nauki dzielimy na formalne (aprioryzm), empiryczne 
(aposterioryzm) i nauki społeczne. Problem klasyfikacji nauk ciągle nurtuje badaczy, bowiem nadal pojawiają się wątpliwości czy dana nauka została prawidłowo przypisana. Przykładowo: naukę historii zaliczymy do nauk empirycznych, do kategorii nauk humanistycznych, w ujęciu szerokim do grupy nauk historycznych. Jednak gdy mamy zaklasyfikować historię medycyny, to już pojawia się problem.

Porównując medycynę z historią i nakładającą się w nich wspólną płaszczyznę jaką jest historia medycyny, możemy zauważyć zarówno różnice, jak i elementy wspólne.

Choć na samym wstępie należy zaznaczyć, iż co do klasyfikacji samej medycyny naukowcy nie są zgodni' ${ }^{1}$. Wskazują oni:

Przez te wszystkie wieki stałymi elementami w medycznej teorii poznania były empiryzm i racjonalizm. Obecnie medycyna wspiera się na dwóch filarach - nauce i sztuce. Dualizm ten można przedstawić wykorzystując parafrazę konfucjańskiej symboliki ying - yang. Poznanie naukowe jest wspierane sztuką tworzenia metodologii poznania. $Z$ kolei sztuka podejmowania decyzji klinicznych korzysta z wiedzy naukowej².

Przyjmijmy jednak, że poprzez metody badawcze, które oferuje medycyna, w porównaniu do nauki historii jest ona nauką aposterioryczną.

Funkcje w obu wyżej wymienionych naukach są bardzo do siebie podobne. Zarówno te zewnętrzne (społeczne), czyli wyjaśnianie (eksplantacja) i przewidywanie (predykcja), jak i te wewnętrzne (poznawcze): ustalanie faktów (obserwacja) i opis (ustalanie praw, budowanie teorii). W humanistyce wyróżnia się jeszcze dwie funkcje nauki, a mianowicie: interpretację i ocenę. Choć moim zdaniem medycyna również w swoim świecie je wykorzystuje, poprzez interpretację, np. wyników badań czy ocenę zdrowia pacjenta.

Jeśli chodzi o problematykę badań medycznych to celem dociekań naukowych w medycynie mogą być zagadnienia etiologii chorób, ich diagnostyki i terapii, a także prognozowanie przebiegu choroby, bezpieczeństwa stosowanych leków i metod terapeutycznych, badania przesiewowe i zapobieganie chorobom.

Etiologia w medycynie oznacza zidentyfikowanie czynników, które przyczyniają się do powstania choroby. Wykrycie owych czynników jest możliwe poprzez poznanie zapadalności na daną chorobę w określonej populacji pewnej grupy ludności. Ważna jest ich dokładna charakterystyka i analiza. Badania takie są bardzo trudne. Wynika to z wieloczynnikowej etiologii chorób i rozwikłanie wzajemnych powiązań wymaga dużego doświadczenia i obszernej wiedzy medycznej³

${ }^{1}$ Zob. szerzej: T. Rzepiński, Wyjaśnianie i rewizja wiedzy w medycynie. Od modeli eksperymentalnych do badań klinicznych, Poznań 2013, s. 23-24.

2 D. Radomski, A. Grzałka, Metodologia badań naukowych w medycynie, Poznań 2011, s. 13.

3 W. Jędrychowski, Zasady planowania i prowadzenia badań naukowych $w$ medycynie, Kraków 2004, s. 11. 
Poprzez diagnozę lekarską należy rozumieć zespół czynności wykonywanych przez lekarza, na podstawie których po pierwsze można określić granice pomiędzy chorobą, a zdrowiem, po drugie postawić rozpoznanie danej jednostki chorobowej. Współcześni lekarze mają do dyspozycji wiele metod diagnostycznych, które pomagają im w rozpoznawaniu chorób. Muszą oni dokonać oceny oraz wyboru odpowiedniej metody, tak by była ona najbardziej skuteczna. Skuteczność takiej metody musi być potwierdzona, w porównaniu do metod nowych, które są dopiero sprawdzane w toku eksperymentów klinicznych ${ }^{4}$.

Zabiegi lecznicze, wynikają z postawionej diagnozy.. Owa definicja obejmuje wszystkie zabiegi terapeutyczne, które lekarz wykonuje sam lub osoba do tego przez niego wyznaczona (np. pielęgniarka). Pojęcie zabiegu leczniczego obejmuje czynności takie jak m.in.: ordynowanie leków, zalecanie i przeprowadzanie operacji chirurgicznych czy zabiegów rehabilitacyjnych. Zadaniem lekarza jest wybór odpowiednich metod terapeutycznych mających na celu wyleczenie chorego lub poprawę jego zdrowia. Pojawia się w tym miejscu w literaturze medycznej problem tak zwanej „,wielkości efektu leczniczego”. Należy pamiętać o negatywnych skutkach podejmowanych działań terapeutycznych, np. zabiegów chirurgicznych (kwestia etyki) $)^{5}$.

Prognozowanie choroby, czyli szacunkowy wpływ danej jednostki chorobowej na zdrowie pacjenta i jego dalsze życie. Jeśli chodzi o bezpieczeństwo leków i innych zabiegów, to zadaniem lekarza jest monitorowanie niekorzystnych skutków oraz efektów ubocznych leków oraz zabiegów. Żeby móc dbać o swoich pacjentów lekarz powinien zlecać badania przesiewowe, w celu jak najszybszego wykrycia bezobjawowej dotąd choroby i objęcia podjęcia odpowiednich kroków terapeutycznych jeśli zostanie ona wykryta. Ważną częścią problematyki badań medycznych jest także zapobieganie, czyli profilaktyka, która ma za zadanie szerzyć świadomość prozdrowotną społeczeństwa, w celu wytworzenia odpowiednich nawyków behawioralnych zapobiegających rozwojowi chorób oraz np. wykonywanie badań okresowych ${ }^{6}$.

Zadania zatem medycyny są dla mnie jasne: rozpoznać, wyleczyć, zapobiegać. Jest ona potrzebna bo ludzie chorowali i będą chorować. A co z historią?

Pytanie takie zadają sobie pewnie często uczniowie zanudzani nieciekawymi lekcjami historii w szkołach. Dorośli nie powinni ulegać podobnym wątpliwościom. Całe doświadczenie człowieka opiera się na wiedzy o przeszłości - swojej własnej, rodzinnej, lokalnej czy narodowej. Pamięć opiera się na wiedzy o przeszłości, czyli historii jako minionej rzeczywistości. Czy nasz rozwój medycyny osiągnąłby taki poziom techniczny, gdyby nie nasi przodkowie? Słowo „historia”

\footnotetext{
4 Tamże, s. 11.

5 Tamże, s. 11-12.

6 Tamże, s. 13-14.
} 
oznacza jednak także ową wiedzę, przedstawianą nam przez zawodowych historyków, publicystów czy nauczycieli ${ }^{7}$.

Cele pracy lekarza zostały przedstawione powyżej. A jaki jest cel historii? Przede wszystkim dążenie do prawdy. Historyk niczym sędzia powinien być obiektywny i ukazujący w swojej pracy wszelkie płaszczyzny wydarzeń. Prawdę o przeszłości można osiągnąć jedynie poprzez odtworzenie całych dziejów, co jest oczywiście niemożliwe. Historycy starają się jednak poprzez pewne metody zbliżyć się do owej prawdy historycznej. Jednak nie każde zdanie prawdziwe zasługuje na miano prawdy naukowej. Zdaniem Platona i Arystotelesa nauka powinna składać się ze zdań ogólnych i koniecznie prawdziwych. Takie wymagania stawiane zdaniom składającym się na wiedzę naukową w zasadzie akceptowano aż do czasów nowożytnych. Obecnie podtrzymuje się zasadniczo wymóg ogólności, chociaż prawo obywatelstwa w nauce mają też zdania szczegółowe i jednostkowe (np. stwierdzenia faktów w historii). Formułuje się też dodatkowe warunki, które powinny spełniać twierdzenia naukowe; do najważniejszych można zaliczy: wysoką ścisłość, informacyjną zawartość i prostotę logiczną. Inaczej rzecz się ma z konieczną prawdziwością twierdzeń naukowych, której jeszcze Kant domagał się. Pomijam tutaj filozoficzną kwestię ustalenia na czym w ogóle polega prawdziwość zdania, zwłaszcza konieczna prawdziwość. Niezależnie od tego czy przyjmiemy tradycyjną, korespondencyjną teorię prawdy, czy jedną z licznych nieklasycznych teorii (np. pragmatyczną), to i tak mamy do czynienia z zasadniczą zmianą postrzegania trwałości wyników poznania naukowego (przynajmniej w naukach empirycznych). Tradycyjnie uważano, że nauka rozwija się w sposób kumulatywny, a wyniki raz uzyskane są trwałym składnikiem wiedzy.

Historia nauki pokazuje jednak coś wręcz odwrotnego - stałą cechą poznania naukowego opartego na doświadczeniu jest jego hipotetyczność i nietrwałość. Jedne teorie zastępują inne chociaż proces ten może trwać wiele pokoleń. T. Kuhn wprowadził pojęcie rewolucji naukowej jako regularnego etapu rozwoju nauki, który prowadzi do zmiany obowiązującego dotąd paradygmatu. Twierdzenia naukowe to zdania, które są w obrębie obowiązującego paradygmatu (zespołu obowiązujących w danym okresie teorii) uznawane, co nie oznacza, że są prawdziwe. Dlatego współcześnie zamiast koniecznej prawdziwości stawia się słabszy warunek wysokiej pewności, rozumiany jako wysoki stopień potwierdzenia przez doświadczenie.

Porównując: etiologia choroby w medycynie, odpowiada licznym czynnikom, z którymi musi zmierzyć się historyk: społecznymi, gospodarczymi, politycznymi, etnicznymi, kulturowymi, itd. Poprzez diagnozę lekarską, w historii upatruję diagnozę historyczną, jako tezę lub antytezę, którą formułuje badacz. Zabiegi lekarskie jawią się jako czynności, czyli metody, które obiera historyk, aby dojść do potwierdzenia lub obalenia wcześniej ustalonej tezy. Zadaniem badacza histo-

\footnotetext{
${ }^{7}$ Zob. szerzej: W. Werner, Wprowadzenie do historii, Warszawa 2012, s. 11-20.
} 
rii, jest także stawianie pewnej prognozy na przyszłość, którą także możemy odnaleźć w medycynie. Być może moje rozumowanie i pewna analogia, którą sama stworzyłam jest, kolokwialnie rzecz ujmując, naciągana, jednak właśnie poprzez proste porównania najłatwiej jest dostrzec podobieństwa.

Nauka ma wyjaśniać. W tradycji polskich rozważań wyjaśnianie obok wnioskowania i dowodzenia traktuje się jako rodzaj rozumowania (Łukasiewicz, Kotarbiński, Czeżowski). Jedno podejście nie wyklucza drugiego. Wyjaśnienie naukowe musi spełniać pewne kryteria. Zdanie opisujące wyjaśniane zjawisko to eksplanandum (zdanie lub pojęcie, które ma być wyjaśnione), natomiast zdania wyjaśniające to eksplanans (wyjaśnienie). Można spotkać się też z określeniami eksplikatum/eksplikans (np. u Karla Poppera). Aby wyjaśnienie można było uznać za naukowe między jego członami musi zachodzić odpowiedni związek natury logicznej, najlepiej wynikanie. Jeżeli ten warunek jest spełniony, to mówimy, że eksplanandum jest następstwem eksplanansa, a samo wyjaśnienie określamy jako dedukcyjne, lub nomologiczno-dedukcyjne (ze względu na występowanie praw naukowych w eksplanansie).

Często jednak przy wyjaśnianiu naukowym zadowalamy się słabszym związkiem obu członów. Jest tak wtedy, gdy w eksplanansie występują prawa statystyczne, ale w eksplanandum stwierdzamy po prostu wystąpienie danego zdarzenia, a nie jego prawdopodobieństwo. Mamy wtedy do czynienia z wyjaśnianiem probabilistycznym, gdyż brak tu wynikania - eksplanans jedynie uprawdopodabnia eksplanandum. Przykładowo, wyjaśniamy fakt nabawienia się przez Kowalskiego grypy, stwierdzając, że Kowalski stykał się z osobami chorymi na grypę (warunki początkowe) oraz, że istnieje wysokie prawdopodobieństwo, iż osoba, która styka się z chorymi na grypę, sama na tę chorobę zapadnie (prawo statystyczne).

Każda nauka ma pewne etapy cyklu badawczego. Model cyklu badawczego przedstawia się następująco: sformułowanie celów badawczych, zbudowanie hipotezy, jej weryfikacja za pomocą odpowiednich metod oraz jej konfirmacja bądź dyskonfirmacja. Ten model, moim zadaniem, jest uniwersalnym dla wszystkich nauk ${ }^{8}$.

Od hipotez wymaga się, aby były wysoce prawdopodobne i zgodne z teorią, do której są dołączane. Wybitny XX-wieczny filozof nauki Karl Popper podkreślał też, że hipoteza musi być falsyfikowalna, tzn. musi być możliwe wykazanie jej (ewentualnej) fałszywości. Inne postulaty, które wysuwa się wobec hipotez to: prostota, ogólność i duża moc predykcyjna, czyli zdolność przewidywania innych zjawisk. Są to cechy istotne przy porównywaniu hipotez konkurencyjnych. Preferowanie rozwiązań najprostszych jest przejawem realizacji tzw. zasady brzytwy Ockhama, w jej współczesnym, metodologicznym sformułowaniu (tradycyjne XIV-wieczne sformułowanie brzmi: nie należy mnożyć bytów bez potrzeby).

${ }^{8}$ Etapy cyklu badawczego w medycynie zob. szerzej: W. Jędrychowski, Zasady planowania i prowadzenia badań naukowych w medycynie, Kraków 2004, s. 19-23. 
Badania historyczne, ze względu na przedmiot badania oraz metody mają inny charakter niż badania medyczne. Choć model postępowania badawczego jest taki sam w medycynie. Wyróżniamy badania: obserwacyjne: retrospektywne (analiza wyników zastosowanego wcześniej postępowania medycznego), prospektywne (włączenie metody diagnostycznej/terapeutycznej i obserwacja jej wyników w przyszłości), przekrojowe oraz eksperymentalne. Między obserwacją, a doświadczeniem, rysuje się wyraźna różnica, a mianowicie w toku badania obserwacyjnego analizuje się zjawisko w takiej postaci, w jakiej ono wystąpiło w przyrodzie, natomiast w doświadczeniu stwarza się warunki ,sztuczne” dla jego przebiegu.

W metodzie retrospektywnej punktem wyjścia jest chory, badanie zmierza do ustalenia czynników, które doprowadziły do danej choroby. Jeżeli ekspozycja na jakieś dane czynniki pojawia się częściej w grupie chorych niż grupie kontrolnej, to wnioskować można, że między badaniami istnieją związki przyczynowo - skutkowe. W metodzie prospektywnej badanie obejmuje pewną grupę osób (kohortę). Badanie polega na prospektywnej obserwacji poszczególnych warstw (podgrup) kohorty dla wykrycia ewentualnych różnic w zapadalności (przeżywalności) tych grup w zależności od interesującej nas charakterystyki badanych osób?

Prof. nauk medycznych Bohdan Trzeciak wyróżnia jeszcze następujące metody badań w medycynie ${ }^{10}$ : historyczno - porównawczą, która to stosowana jest w badaniach nad przebiegiem zjawisk i procesów zachodzących w przeszłości (historia medycyny). Metoda ta jest najbliższa owym dwóm omawianym naukom. Opiera się ona w głównej mierze na wiedzy źródłowej i pozaźródłowej, dzięki której to historyk ustala fakty historyczne poprzez ich wyjaśnianie przyczynowe i tworzenie odpowiedzi na postawione sobie wcześniej pytania czy hipotezy ${ }^{11}$. Należy jednak pamiętać, że źródła nie są śladami po faktach historycznych czy po czynach ludzi. Dostarczają nam one jedynie informacji, które umożliwiają nam konstruowanie faktów historycznych ${ }^{12}$. Zadaniem historyka jest interpretacja źródeł. Wiemy zatem, że wiedza źródłowa opiera się na konkretnych źródłach, natomiast wiedzę pozaźródłową możemy podzielić jeszcze na potoczną i naukową. Wiedza potoczna to wiedza ogólna, popularna, współczesna, natomiast naukowa to wiedza: historyczna, teoretyczna, merytoryczna z innych nauk i metodologiczna. Jak widać historyk musi mieć opanowaną szeroką wiedzę, aby mógł on ukształtować swój pogląd na dzieje oraz ich poznawalność.

Kolejną z metod, na którą powołuje się B. Trzeciak, jest metoda statystyczna. Występująca ponownie i w medycynie i w historii. Dla historyków zajmujących się historią gospodarki czy demografią, wszelkiego rodzaju wykresy, tabele

\footnotetext{
9 Tamże, s. 22.

${ }^{10}$ Zob. szerzej: T. Rzepiński, Wyjaśnianie i rewizja ..., s. 237-243.

${ }_{11}$ Zob. szerzej: J. Topolski, Metodologia historii, Warszawa 1984, s. 349.

${ }_{12}$ Zob. szerzej: tenże, Wprowadzenie do historii, Poznań 1998, s. 34-39.
} 
i zestawienia nie są obce. Metoda statystyczna bowiem polega na maksymalnym wykorzystaniu informacji zawartych w źródłach statystycznych: rocznikach, materiałach sprawozdawczych przedsiębiorstw lub instytucji społecznych, spisach ludności. Ma na celu uchwycenie tendencji, prawidłowości czy zależności dotyczących struktury społecznej, rozwoju społecznego, albo zależności pomiędzy jednostkami, grupami czy w końcu zbiorowościami społecznymi.

Następną z metod jest metoda monograficzna. Zarówno z punktu widzenia medycyny, jak i historii dąży ona do uchwycenia zjawisk całościowo, integralnie. Jest to metoda chwalona przez modernistycznych historyków, którzy w centrum stawiali badania nad zjawiskami masowymi. Według nich świat zbudowany był strukturalnie i racjonalnie. Twierdzono, iż w akcie poznania jest możliwe precyzyjne odwzorowywanie rzeczywistości. Po owych cechach widać od razu podobieństwo do nauk przyrodniczych i wyłaniającego się determinizmu. Zatem nic dziwnego, że można doszukiwać się podobieństw. Ujmowanie pewnych zagadnień historycznych jako całościowych problemów było stosowane i pewne całościowe monografie nadal powstają. Metoda ta zarówno wśród historyków, jak i lekarzy poddawana jest krytyce. Historia wskazuje ją jako niewłaściwą z powodów badania zjawisk i procesów społecznych, na których cierpi indywidualizm i jednostka. Nie wszystko z przeszłości, bowiem można poznać za pomocą rozumu (np. religia, obrzędy) i że odwzorowanie całej rzeczywistości jest zadaniem niemożliwym. $\mathrm{Z}$ punktu widzenia medycznego B. Trzeciak stawia zarzut koncentracji uwagi na zjawiskach jednakowych oraz stosowanie jednostronnego opisu rzeczywistości bez próby teoretycznego uogólnienia.

Zarzut ten jednak traci swoje ujemne cechy, jeżeli na gruncie tej metody pojawia się opis naukowy:

- Dokonany wyłącznie i konsekwentnie z jednego, ściśle określonego i uświadomionego punktu widzenia;

- Opis możliwie szczegółowy (acz jednostronny)

- Opis możliwie przedmiotowy, możliwie rzeczowy $(\ldots)^{13}$.

Dalszą metodą jest w medycynie tzw. metoda dokumentów osobistych.

Stosowana jest $\mathrm{w}$ badaniach przejawów życia społecznego oraz subiektywnych postaw i zachowań jednostek i ich psychospołecznych uwarunkowań, indywidualnych doświadczeń w określonych sytuacjach i stosunkach środowiskowych ${ }^{14}$.

${ }^{13}$ B. Trzeciak, Podstawy metodologii badań medycznych. Skrypt dla studentów wydziałów fizjoterapii, pielęgniarstwa $i$ kosmetologii, Łódź-Kołobrzeg 2010, s. 13-14.

14 Tamże, s. 14. 
Widać tutaj zdecydowany nacisk na indywidualność. Mnie jako historykowi zaraz przychodzi na myśl pewna analogia, związana z badaniami historycznymi, a mianowicie: mikrohistoria ${ }^{15}$. Owa praktyka historiograficzna polega na historycznym opisie niewielkich przestrzeni terytorialnych i czasowych. Silnie akcentuje problemy życia codziennego, świadomości, przekonań oraz obyczajów członków społeczności lokalnych. Zagadnienia te są często pomijane przez tradycyjną historiografię zajmującą się głównie wielkimi procesami i wybitnymi jednostkami. Badania mikrohistoryczne wspomagane są często antropologią i naukami o kulturze, seksualności czy religii ${ }^{16}$.

Kolejną z metod jest metoda sondaży opinii, która w swojej formule nawiązuje bardzo do badań i analiz statystycznych. W medycynie są to ankiety wypełnianie przez pacjentów. Za przykład może posłużyć ankieta dotycząca trybu życia, na podstawie której lekarze mogą wnioskować o konieczności rozpoczęcia działań profilaktycznych (np. zaprzestanie palenia papierosów). W historii pod tą metodą odnalazłabym wywiad, który zostaje przeprowadzony, np. z uczestnikami powstania warszawskiego. Na pewno nie ma on charakteru surowej sondy czy ankiety, ale forma jest zbliżona.

Ostatnią z metod, którą chciałabym omówić jest metoda eksperymentalna. I jest to metoda, która odróżnia od siebie wyżej omawiane nauki. Występuje tylko i wyłącznie w naukach ścisłych, bowiem w naukach historycznych jest ona niemożliwą do wykonania. Charakteryzuje się innym niż w obserwacji stosunkiem osoby badanej do zjawiska badanego. Obserwując nie zmienia się badanego zjawiska, natomiast eksperyment naukowy polega na czynnej jego modyfikacji, dążąc do poznania zależności przyczynowych pomiędzy składnikami lub warunkami jego przebiegu. Podobnie jak w metodzie obserwacyjnej do badań przystępuje się z przygotowanymi punktami widzenia i założenia; następuje tu także notowanie przebiegu i wyników. Obserwacja stanowi część składową eksperymentu.

Wiele prac badawczych prowadzi się metodami obserwacyjnymi i eksperymentalnymi łącznie; niejako podchodząc z dwóch stron do studiów nad tą samą sprawą. Wyróżnia się eksperymenty naturalne i eksperymenty laboratoryjne. Eksperyment naturalny jest analizą przebiegu zjawiska, wywołanego i kontrolowanego, ale w warunkach naturalnych, między innymi w warunkach działalności ludzkiej uprawianych z innych względów niż poznawanie prawdy naukowej. Stosuje się tu na przykład grupy równoważne: grupę eksperymentalną i grupę

15 J. Topolski, Wprowadzenie..., s. 132-136.

${ }^{16}$ Przykładem mikrohistorii jest książka autorstwa Emmanuela Le Roy Ladurie, Montaillou - wioska heretyków. Montaillou leżało w podpirenejskim hrabstwie Foix, w górach Ariège. Praca opisuje wewnętrzny świat katarskiej wioski, do której przybywa trybunał inkwizycyjny (z jego archiwów Le Roy Ladurie czerpał informacje). Praca pokazuje całość wiejskiego życia przełomu XIII i XIV wieku: spory wewnątrz wspólnoty, seksualność bohaterów czy ich postawy wobec zagrożenia sądu inkwizycyjnego. Innym przykładem jest praca Ser i robaki. Wizja świata pewnego mlynarza z XVI w. Carlo Ginzburga (1976). 
kontrolną, by porównać zachowanie pewnej zbiorowości, gdzie wprowadzony zostaje nowy czynnik i zbiorowości, gdzie zmiana taka nie nastąpiła.

Eksperyment laboratoryjny wykonywany jest w sztucznie stworzonym środowisku - tradycyjnie w ograniczonym, zaopatrzonym w przyrządy miejscu, jakim jest laboratorium, z zastosowaniem odpowiednich instrumentów. Istotą takich eksperymentów jest izolacja zjawisk w postaci układów odosobnionych. Jest szeroko stosowany w naukach ścisłych, naukach technicznych, naukach biologicznych i w naukach medycznych ${ }^{17}$. Najważniejszym wzorcem badań eksperymentalnych jest metoda jedynej różnicy (Ceteris paribus), opracowana przez Johna Stuarta Milla i podana w jego Systemie logiki. Mówi ona, że jeśli pewne zjawisko jest jednakowe z innym zjawiskiem pod względem wszystkich cech z wyjątkiem jednej, to różnice w jego przebiegu należy przypisać właśnie tej różnicowej cesze. Na niej opierają się eksperymenty wykonywane za pomocą grup równoważnych. Problemem może być tu znalezienie grup odpowiednio równoważnych, a aby zmniejszyć rozmiary błędów wnioskowania stosuje się więc grupy dostatecznie liczne.

Wymienione przeze mnie metody pokazują liczne podobieństwa i zarazem różnice między naukami historycznymi i medycznymi. Płaszczyzną, w której obydwie nauki zbliżyły się ze sobą najbardziej jest niewątpliwie historia medycyny. Jednak zarówno historyk, jak i lekarz będzie podchodził do niej z innego punktu widzenia, co innego będzie dla nich ważne. Źródła, na których pracują, metody ich badań nie będą różniły się (mowa o historii medycyny), jednakże cele jakie obaj badacze będą chcieli osiągnąc będą inne.

Nieskromnie posłużę, się swoim przykładem. Badając w jednym z rozdziałów mojej rozprawy doktorskiej medyczne szkolnictwo wojskowe w II Rzeczypospolitej, ważne są dla mnie jako historyka m.in: organizacja owego szkolnictwa, liczba absolwentów, najważniejsze szkoły medyczne, które kształciły oficerów. Dla osoby studiującej medycynę, myślę, że ważniejsze byłyby aspekty biologiczno - medyczne, tzn.: metody przeprowadzania operacji chirurgicznych, czy też zagadnienie chorób występujących wśród uczniów owych szkół itp.

Zatem reasumując, sadzę, że historyk medycyny i lekarz zajmujący się historią medycyny mają wiele wspólnych płaszczyzn metodologicznych, na których to wzajemnie mogą się wspierać. Wspólnie im bowiem łatwiej będzie podołać odtworzeniu przeszłości. Jej badanie z wielu perspektyw przyczyni się do lepszego poznawania prawdy.

W niniejszym tekście poruszyłam tylko najważniejsze kwestie związane z metodologią nauk, dokonując próby porównania płaszczyzn - historii i medycyny. Uważam, że zacieranie się granic nauk, zmusza obecnie naukowców do prób odnajdywania się w innych jej dziedzinach. Moje analogie, mogą wydawać się niewłaściwe i jawić się jako sztuczne twory. Uważam, jednakże, iż próba takiego porównania musiała zaistnieć. Medycyna ma wydźwięk niejednoznaczny.

\footnotetext{
${ }^{17}$ Zob. szerzej: J. Pieter, Ogólna metodologia pracy naukowej, Wrocław 1967.
} 
Jej „,charakter sztuki” ma wymowę etyczną, a tym samym humanistyczną. Czym jest medycyna? Nauką obejmującą całość wiedzy o zdrowiu i chorobach człowieka oraz sposobach ich zapobiegania oraz ich leczenia. Czym jest historia? Nauką badającą przeszłość, a w znaczeniu ścisłym badaniem działań i wytworów ludzkich, aż do najstarszych poświadczonych pismem świadectw. W obydwóch definicjach nacisk kładziony jest na człowieka. Ja zatem nie mam wątpliwości, iż elementy wspólne w obu naukach występują.

Aleksandra Rybińska

\section{THE ISSUE OF RESEARCH METHODOLOGY IN HISTORICAL AND MEDICAL SCIENCES - THE PROBLEM OF INTERDISCIPLINARITY}

Nowadays, interdisciplinary research is becoming more popular. With his problem has to face many researchers. The specificity of the test procedures across the various fields different from each other. There are ranges of research that are difficult to classify into one cognitive methods. As a PhD student of history at the University of Lodz, who wrote the work in the history of medicine in the military health care in the years 1918-1939, I encountered such a problem. Status of medicine in my research method is a humanist. I decided to your thoughts and experiences in the field of learning and research in these two areas to collect and present, as a single text in the form of a scientific paper.

The term research methodology understand the science of measurement method occurring phenomena, which the researcher wants to measure. It is a certain set of rules on how to study, who examine, then examine where to study. The aim of the research is to develop a methodology for better and better ways of measuring/testing phenomena ongoing improvement. The better method is the more accurate test results are obtained. The key to a reliable measurement of the phenomenon of interest to us is the selection of appropriate research methods/techniques of measurement. Each branch of science has developed and are developing their own research methods, in order to best measure the phenomena of interest to them.

The purpose of my paper is to present, differences and similarities in medical science research methodology and historical sciences. The appearance of a "human face medicine". I want to show you how to: we historians perceive problems in medicine (medical history), and how we deal with science, which is considered to be close. Two seemingly different environments, and having a lot in common. 